\title{
Prevalence and Factors Associated to the Epidemic Neuropathy in a Population Assisted by a Family Doctor in Cuba
}

\author{
Antonio E Pérez Rodríguez/ ${ }^{+}$, Carlota Pereira, Flora Olga Hernández, Pedro \\ Más Lago, Angel Balmaseda, Reinaldo Menéndez
}

\author{
Instituto de Medicina Tropical "Pedro Kourî”, Autopista Novia del Mediodía, km 6, Municipio Lisa, \\ Ciudad de la Habana, Cuba
}

\begin{abstract}
With the outbreak of an epidemic neuropathy (EN) of unknown ethiology, a study of the prevalence and factors associated to the disease was carried out in the Zamora community, municipality of Marianao, Havana City. There were 11 patients identified with EN for a prevalence rate of 1.7/100. The major risk group was the one between 45 and 64 years of age, female sex, black skin. In the univaried analysis, a high prevalence ratio $(P R)$ was found linked to beverage intake $(P R=5.3295 \%$; confidence intervals $(C I)=1.2-24.4)$, frequent drugs intake $(P R=6.59 ; C I=1.8-24.6)$, consumption of edible of non certified fats $(P R=4.48 ; C I=1.2-16.7)$ and the smoking habit $(P R=3.6 ; C I=1.1-12.2)$. More than $73 / 100(C I=$ 68.7-78.3) of the people under serologic study were infected with Coxsakie virus A-9 (strain 47) isolated from a patient still under research. It seems there are many factors like linder intake, antecedents of hemorrhagic conjuntivitis, nutritional aspects and others that, with the virus isolated were associated with this epidemiologic situation.
\end{abstract}

Key words: epidemic neuropathy - prevalence - Coxsackie virus - risk factors - epidemiological study - Cuba

From 1 January 1992 through 14 January 1994 the Ministry of Public Health of Cuba (MINSAP) identified 50,862 cases of a neuropathy in residents of Cuba. It was called epidemic neuropathy (EN). The disease has included an optic form that is characterized by a sub-acute onset, decreased visual acuity, decreased color vision, and/or central or cecocentral scotomata and a peripheral form with a predominantly sensory neuropathy and evidence of posterior spinal cord involvement. In some cases it was possible to find simultaneous optic and peripheral neuropathy (MINSAP 1994).

There are reports of the disease in some tropical areas and developed countries where they have not been properly clarified, though, some nutritional malabsortion, infectious and toxical factors have been pointed out (Román et al. 1985). Some chronic poisonings due to cassava flour intake and other cyanogenic foods that have been reported as big tropical neuromyelopathy epidemies, mainly in Africa should be stressed (Rosling 1988, Tylleskar et al. 1991).

It is also important to point out that in Japan, between 1955 and 1970 there were about 10,000

\footnotetext{
${ }^{+}$Corresponding author. Fax: 53-7-21.5957

Received 14 July 1995

Accepted 14 June 1996
}

patients registered with a subacute myelo-optical neuropathy (SMON) with a clinical description similar to ours, except for the prodome abdominal symptoms. It was considered that this neuropathy had a probable infectious ethiology, but this was not corroborated, and the conclusion was that the main cause was a drug named clioquinol (Kono 1975).

In Cuba another biological agent (Coxsackie virus) has been isolated from some patients (Más Lago et al. 1995). To determine the role of the Coxsackie virus further studies are required because there is a slight evidence of an infectious and communicable disease.

Since these processes are ethiologically complexes, the aim of this paper is to identify a relationship between some factors and the occurrence of this disease, and contribute to its epidemiologic characterization.

\section{MATERIALS AND METHODS}

On 29 March 1993, a study on EN punctual prevalence was carried out, according to diagnostic criteria (Table I) established nationwide (MINSAP 1993). It was made among the 656 inhabitants assisted by the family doctor office number 1 , in the Zamora community, located at the municipality of Marianao, Havana City.

The survey was undertaken by ten physicians previously trained for that purpose, and the information dealt with personal features, toxic and bio- 
TABLE I

Guidelines for clinical diagnosis of epidemic neuropathy MINOR CRITERIA

Optic form $^{a}$

1. Decreased visual acuity (below 20/25)

2. Decreased color vision (failure to identify two or more of the first eight Ishihara plates)

3. Bilateral central or cecocentral scotomata

4. Decreased contrast sensitivity

5. Bilateral loss of optic nerve fibers in the papillomacular bundle

Peripheral form ${ }^{b}$

1. Peripheral sensory symptoms (tingling, cramps, numbness, and/or burning sensation)

2. Decreased perception of vibration or pin prick

3. Altered deep tendon reflexes in lower limbs, generally with decreased or absent ankle reflex with or without patellar hyperreflexia
1. Temporal pallor of optic disk (one month after symptom onset)

2. Photophobia or ocular burning sensation

3. Loss of horizontal smooth pursuit

$a$ : a confirmed diagnosis required at least four major criteria.

$b$ : a confirmed diagnosis required three mayor criteria or two major criteria and a minor criterion, always including peripheral sensory symptoms.

logic risks, vaccine exposure, previous contacts with patients, useful data regarding other diseases and aspects concerning environmental hygiene; all of them before the onset of symptoms for EN patients and the corresponding period from the interview by the remaining inhabitants (Table II).

The serological survey was carried out on the whole population, but only 342 of them (52.1\%) volunteered between 5 and 12 June. The survey identifyed the presence of antibodies against Coxsackie A-9 virus strains 47 isolated from the cerebral spinal fluid (CSF) in one of the EN patients by means of an ELISA technique with a cut off value of 45 or more of inhibition, considering this criterium as virus exposure with or without disease (Balmaseda et al. 1995)

Any infection acquired three months before the EN symptoms began was considered a previous disease, and the same for the person without disease, after the survey was undertaken.

In the case of drug exposure antecedents, it was considered that a usual drug intake three months before the EN symptoms and, in relation to vaccination antecedents, a year before. The same time was considered for healthy patients from the moment when the survey was made.

Remarkable pathologic antecedents were registered regardless of time since that could explain the different individual responses or reactions of previous sensibility.
1. Urinary urgency, nocturia, increased frequency or incontinence

2. Autonomic dysfunction (coldness, heat or excessive sweating of hands or feet, palpitations or tachycardia)

3. Other signs and symptoms including hearing loss, dysphagia, dysphonia, sensory ataxia, constipation diarrhoea, sexual impotence, irritability, and sleep disturbance 
TABLE II

Definitions of risk factors variables

\begin{tabular}{|c|c|}
\hline Variables & Definitions \\
\hline Occupation & Occupational categories within the last three months \\
\hline Color of the skin & $\begin{array}{l}\text { Depending on the color of the skin and the hair characteristics } \\
\text { of the individuals }\end{array}$ \\
\hline Pesticide & Contact to pesticide for more than thirty days in the last year \\
\hline Smoking habit ${ }^{a}$ & $\begin{array}{l}\text { Subjects who smoked five or more cigarettes per day for more } \\
\text { than } 30 \text { days }\end{array}$ \\
\hline Alcoholic beverages $^{a}$ & $\begin{array}{l}\text { Consumption (more than } 30 \mathrm{ml} \text { ) of alcoholic beverages at least } \\
\text { three times per week in the last three months }\end{array}$ \\
\hline Coffee $^{a}$ & $\begin{array}{l}\text { Consumption of at least a cup of coffee daily for more } \\
\text { than a month }\end{array}$ \\
\hline Infusions or herb decoction & Plants and roots in bush tea (consumption a glass daily) \\
\hline Pharmaceutical drugs & Daily drugs consumption for the last three months \\
\hline $\begin{array}{l}\text { Soap of non-certified }{ }^{a} \\
\text { origin }\end{array}$ & $\begin{array}{l}\text { When acquired through other sources that are not the State } \\
\text { distribution }\end{array}$ \\
\hline $\begin{array}{l}\text { Fat of non-certified }{ }^{a} \\
\text { origin }\end{array}$ & $\begin{array}{l}\text { When acquired through other sources that are not the State } \\
\text { disribution }\end{array}$ \\
\hline Previous contact $\mathrm{EN}^{b}$ & $\begin{array}{l}\text { Contact with patients of EN for the previous } \\
\text { three months }\end{array}$ \\
\hline Animals & $\begin{array}{l}\text { Presence of cats, dogs, chickens, and other domestic animals } \\
\text { at home }\end{array}$ \\
\hline Vectors & Presence of mosquitos, flies, rodents, cockroaches, etc. at home \\
\hline Previous disease & Any infection acquired on the previous three months \\
\hline $\begin{array}{l}\text { Vaccines or another } \\
\text { substance injected }\end{array}$ & If one was vaccinated or injected with some drug last year \\
\hline Previous trips & If one travelled last year \\
\hline Serologic + & Cut off value of 45 or more of inhibition by ELISA technique \\
\hline $\begin{array}{l}\text { Antecedent of some } \\
\text { diseases }\end{array}$ & $\begin{array}{l}\text { Asthma, allergy, varicella, measles, mumps, hemorrhagic } \\
\text { conjuntivitis, dengue, rubella }\end{array}$ \\
\hline
\end{tabular}

$a$ : in each of these variables we asked about the source to obtain it; $b$ : epidemic neuropathy; Time refered: in EN patients is the interval of time before the symptoms onset; in non-EN persons is the interval of time before the interview.

TABLE III

Sanitation classification

\begin{tabular}{llll}
\hline Aspects & Good (A) & Fairly good (B) & Bad (C) \\
\hline Sewage & $\begin{array}{l}\text { Sewerage } \\
\text { system } \\
\text { Dairy }\end{array}$ & Cesspool & $\begin{array}{l}\text { Cesspool and shedding } \\
\text { over opened areas }\end{array}$ \\
$\begin{array}{l}\text { Collection } \\
\text { Streets }\end{array}$ & $\begin{array}{l}\text { Two times a } \\
\text { week }\end{array}$ & $\begin{array}{l}\text { Shedding over } \\
\text { opened areas }\end{array}$ \\
Residence & $\begin{array}{l}\text { Asphalt in good } \\
\text { conditions and side } \\
\text { walk }\end{array}$ & $\begin{array}{l}\text { Asphalt in fairly } \\
\text { conditions, no side } \\
\text { walk }\end{array}$ & No asphalt, no side walk \\
Masonry & Wood house & $\begin{array}{l}\text { Wood houses usualy } \\
\text { in bad conditions }\end{array}$ \\
\hline
\end{tabular}


product terms need to be included in the model. It was assessed at $\mathrm{p}<0.10$ level using the likelihood ratio test.

\section{RESULTS}

A total of 656 inhabitants belonging to 196 families were surveyed, identifying 11 cases of EN, for a general prevalence of $1.7 / 100$; all adults between 25 and 64 years of age showed a higher rate, between 45 and 64 (Table IV). In addition, the female sex (rate 2.3/100) and the black race (rate 6.1/100) showed higher prevalence, together with military personel, professionals, service workers, and other workers. There were no associations found within the previously mentioned variables. When dividing the area into zones $(\mathrm{A}, \mathrm{B}, \mathrm{C})$, we found that prevalence was higher in zone $\mathrm{A}$ (rate 3.0/100), and it matches with better hygienic sanitary conditions, the rest having lower rate and worse hygienic conditions (Table V).

The individual analysis of some habits or toxic factors (Table VI) showed a strong association with the usual consumption of some pharmaceutical drugs three months before the ocurrence of the disease $(\mathrm{PR}=6.59 ; \mathrm{CI}=1.8-24.6)$, linder infusion intake $(\mathrm{PR}=5.32 ; \mathrm{CI}=1.2-24.4)$, consumption of edible fat of non-certified origin ( $\mathrm{PR}=4.48 ; \mathrm{CI}=1.2$ 16.7), and smoking habit ( $\mathrm{PR}=3.60 ; \mathrm{CI}=1.1-12.2)$.

When stratifying the group between 25 and 64 years of age, where most of patients are gathered, the PR decreased slightly but the smoking habit decreased markedly to 2.12 . It is relevant that three out of four patients were passive smokers.

The antecedents of dengue, allergy, hemorrhagic conjuntivitis and rubella, with the following specific rates respectively: 9, 8.5, 6.5 and 6.0/ 100 , were the highest found. It is interesting to note the lower rates of the patients without previous diseases and there were no EN patients with records of being exposed to vaccines, and fertilizers (Table VII). Only 9 patients out of 252 inhabitants with antibodies against the viral agent under study (Cox-

\section{TABLE IV}

Prevalence of epidemic neuropathy according to age, sex, skin color and occupation. Zamora, 29 May 1993

\begin{tabular}{|c|c|c|c|}
\hline Total & $(656)$ & Patients & $\begin{array}{l}\text { General } \\
\text { prevalence/100 }\end{array}$ \\
\hline Age group & & 11 & $\begin{array}{l}1.7 \\
\text { Specific } \\
\text { prevalence/100 }\end{array}$ \\
\hline $25-44$ years $^{a}$ & $(242)$ & 5 & 2.1 \\
\hline $45-64$ years $^{a}$ & (112) & 6 & 5.4 \\
\hline \multicolumn{4}{|l|}{ Sex } \\
\hline male & (308) & 3 & 1.0 \\
\hline female & $(348)$ & 8 & 2.3 \\
\hline \multicolumn{4}{|l|}{ Skin color } \\
\hline white & $(443)$ & 8 & 1.8 \\
\hline black & (33) & 2 & 6.1 \\
\hline mongrel & $(180)$ & 1 & 0.6 \\
\hline \multicolumn{4}{|l|}{ Occupation $^{b}$} \\
\hline workes & (93) & 4 & 4.3 \\
\hline services & (66) & 3 & 4.5 \\
\hline professional & (19) & 1 & 5.3 \\
\hline military & (18) & 1 & 5.6 \\
\hline technician & (66) & 1 & 1.5 \\
\hline pensioners & (53) & 1 & 1.9 \\
\hline
\end{tabular}

$a$ : all other age groups are excluded since they had no patients; $b$ : population over 14 years of age

\section{TABLE V}

Prevalence of epidemic neuropathy according to residence regions.

Zamora, 29 May 1993

\begin{tabular}{ccc}
\hline Region (population) & Patients & Prevalence/100 \\
\hline A (101) & 3 & 3.0 \\
B (184) & 2 & 1.1 \\
C (371) & 6 & 1.6 \\
\hline Total (656) & 11 & 1.7 \\
\hline
\end{tabular}

TABLE VI

Prevalence and relative risk of epidemic neuropathy according to some risk factors. Zamora, 29 May 1993

\begin{tabular}{lcccc}
\hline Factors (population) & & Patients & Specific rates/100 & Prevalence ratio \\
\hline Smocking habit & $(214)$ & 7 & 3.3 & $3.60(1.1-12.2)$ \\
Passive smoking & $(411)$ & 3 & 0.7 & $0.22(0.1-0.82)$ \\
Alcoholic beverages & $(217)$ & 3 & 1.4 & $0.76(0.2-2.84)$ \\
Coffe & $(389)$ & 9 & 2.3 & $3.10(0.7-14.2)$ \\
Infusions & $(301)$ & 9 & 3.0 & $5.32(1.2-24.4)$ \\
Pharmaceutical drugs & $(188)$ & 8 & 4.2 & $6.59(1.8-24.6)$ \\
Fats of non-certified origin & $(245)$ & 8 & 3.3 & $4.48(1.2-16.7)$ \\
\hline
\end{tabular}

( $95 \%$ confidence intervals) 
sackie A-9 virus strain 47), showed that exposition (rate 3.6/100).

In the unvaried analysis, the PR of every antecedent was the following: rubella $(\mathrm{PR}=29.11$; $\mathrm{CI}=3.8-225.6)$, measles $(\mathrm{PR}=10.53$; $\mathrm{CI}=3.3-35.6)$, varicela $(P R=17.72 ; C I=2.3-137.6)$, dengue $(\mathrm{PR}=10.53 ; \quad \mathrm{CI}=3.3-35.6), \quad$ hemorrhagic conjuntivitis $(\mathrm{PR}=7.37 ; \mathrm{CI}=2.3-23.6)$ and allergy ( $\mathrm{PR}=6.66 ; \mathrm{CI}=1.85-24.0)$.

Among the 342 inhabitants with serologic study, $252(73.7 \%)$ had positive antibodies against Coxsackie A-9 virus (strain 47) isolated. The rate of exposition ranged between 68.7 and $78.3 \%$ (IC$95 \%$ ). The group between 6 and 14 years of age had the highest percentage of positivity $(97.7 \%)$ and the group of 45 years or more had $55 \%$ of positivity (Table VIII).

The PR of antibodies according to the residence zones was higher in zone A $(85.7 \%)$, a sig- nificant difference when compared to regions B and C (Table IX).

According to the multivaried logistic regression analysis made on that population with the serological study to learn about the role of the biological agent in this process, a greater correlation to age, linder intake, the consumption of edible fat of non-certified origin and antecedents of hemorrhagic conjuntivitis was found. Despite the results shown on Table $X$, smoking still remains nonsignificant. Moreover, if we supress this variable, the positive serology coefficient will decrease, and the $\mathrm{p}$ value will increase to 0.0586 .

If the same analysis is done on individuals of 25 years old and over, the smoking habit variable increases the coefficient (1.3010) although, it remains statistically non-significant $(\mathrm{p}=0.1431)$. Other variables, including virus exposure (Coef. $3.1005 \mathrm{p}=0,0231$ ) improve.

\section{TABLE VII}

Prevalence and prevalence ratio of epidemic neuropathy according to some interesting antecedents. Zamora, 29 May 1993

\begin{tabular}{lrccc}
\hline Antecedents (population) & & Patients & Specific rates/100 & Prevalence ratio \\
\hline Asthma & $(88)$ & 2 & 2.3 & $1.44(0.32-6.54)$ \\
Allergy & $(35)$ & 3 & 8.5 & $6.66(1.85-24.0)$ \\
Varicella & $(236)$ & 10 & 4.2 & $17.72(2.3-137.6)$ \\
Measles & $(231)$ & 10 & 4.3 & $18.44(2.4-143.2)$ \\
Mumps & $(219)$ & 8 & 3.6 & $5.30(1.4-19.8)$ \\
Rubeolla measles & $(168)$ & 10 & 6.0 & $29.11(3.8-225.6)$ \\
Hemorrhagic conjuntivitis & $(92)$ & 6 & 6.5 & $7.37(2.3-23.6)$ \\
Denge & $(67)$ & 6 & 9.0 & $10.53(3.3-35.6)$ \\
Previous disease & $(151)$ & 3 & 1.3 & $1.19(0.3-4.4)$ \\
Epidemic neuropathy contact & $(206)$ & 4 & 1.9 & $1.25(0.4-4.2)$ \\
Serology + & $(252)$ & 9 & 3.6 & $1.61(0.35-7.3)$ \\
Vaccine & $(135)$ & 0 & 0.0 & 0 \\
Plaguicide & $(43)$ & 0 & 0.0 & 0 \\
\hline
\end{tabular}

( $95 \%$ confidence intervals)

\section{TABLE VIII}

Epidemic neuropathy. Prevalence of antibodies against the viral antigen isolated according to the age groups. Zamora, 5-12 June 1993

\begin{tabular}{lrccc}
\hline \multicolumn{2}{l}{ Age groups } & Positives & \multicolumn{2}{c}{ Prevalence/100 } \\
\hline $0-5$ & $(5)$ & 1 & 20.0 & $(1.1-70.1)$ \\
$6-14$ & $(44)$ & 43 & 97.7 & $(86.5-99.8)$ \\
$15-24$ & $(66)$ & 58 & 87.9 & $(76.9-94.3)$ \\
$25-44$ & $(131)$ & 97 & 74.0 & $(65.5-81.1)$ \\
$45-64$ & $(69)$ & 38 & 55.1 & $(42.7-66.9)$ \\
$65 \mathrm{y}+$ & $(27)$ & 15 & 55.6 & $(35.6-73.9)$ \\
\hline Total & $(342)$ & 252 & 73.7 & $(68.7-73.3)$ \\
\hline
\end{tabular}

( $95 \%$ confidence intervals)
TABLE IX

Epidemic neuropathy. Prevalence of antibodies against the viral antigen isolated according to the residence regions. Zamora, 5-12 June 1993

\begin{tabular}{lrcc}
\hline \multicolumn{2}{c}{ Regions } & Positives & \multicolumn{2}{c}{ Prevalence/100 } \\
\hline A & $(63)$ & 54 & $85.7(74.1-92.9)$ \\
$\mathrm{B}$ & $(100)$ & 71 & $71.0(60.9-79.4)$ \\
$\mathrm{C}$ & $(179)$ & 127 & $70.9(63.6-77.4)$ \\
\hline
\end{tabular}

(95\% confidence intervals)

Proportion tests

A-B $Z=2.161 \quad \mathrm{p}=0.0153$

A-C $\quad Z=2.326 \quad p=0.0100$ 
TABLE $X$

Epidemic neuropathy. Multivariated logistic regression analysis of all variables in the population with serological study. Zamora

\begin{tabular}{lccccr}
\hline Variables & Coefficient & P value & PR & PR (lower) $^{a}$ & PR (upper) \\
\hline Serology + & 2.6240 & 0.0225 & 13.7 & 1.4 & 131.2 \\
Age & 0.0737 & 0.0146 & 1.1 & 1.0 & 1.1 \\
Smoking & 0.9406 & 0.2437 & 2.5 & 0.5 & 12.4 \\
Linder & 3.8076 & 0.0000 & 45.0 & 7.4 & 273.4 \\
Hemorragic conjuntivitis & 2.0143 & 0.0171 & 7.5 & 1.4 & 39.3 \\
Fats of non-certified origin & 2.4420 & 0.0039 & 11.5 & 2.2 & 60.5 \\
\hline
\end{tabular}

PR: prevalence ratio; $a$ : prevalence ratio confidence limits

\section{DISCUSION}

In the family doctor health care office number 1 , of the Zamora community, the prevalence rate was about $2 / 100$, the higher rates corresponding to the group of females between 45-64 years of age. It was similar in the rest of the country. The high rates among black people and the fact of not finding common labor risk should be underlined. In general we found that the factors associated to the disease were hemorrhagic conjuntivitis in the antecedents, drugs and linder intake, the consumption of edible fat of non-identified origin and the contact with a biological agent that is yet under study.

It should be pointed out that all the drugs consumed by these patients were sedatives; however there were no new drug or differences in the consumption of some specific drug, but mainly Valium (four patients) and Miltown (three patients).

Although the epidemic of Japan (SMON) was only caused by the clioquinol intake (Tamura 1975), there are many reasons that do not apply to the case of Cuba. There have been changes in the Cuban's nutritional habits due to the circumstances that we are facing now. There is an increase in herb infusions intake strongly associated to linder $(\mathrm{PR}=16.86)$ well-known because of its sedative properties. The intake of linder and drugs having similar effects induces us to think that stress may also be a factor that increases susceptibility to this disease. Besides, the substances derived from linder might also contribute to this phenomenon; but further studies are necessary.

Concerning the consumption of edible fat of non-identified origin, there is not a clear explanation, because it was not possible to identify any illegal or altered production of this product; there was only one report of sale out of the state market due to the present situation. Nevertheless, this should be deeply studied to clarify its possible association to the disease. All of these aspects ratify that there has been a reduction of the intake of some nutritients as well as some changes in the population's diet as a result of the economic difficulties. However, there are no evidences of malnutrition in our patients. Thus, although it might be one of the many factors, it is not the main cause, as in the case of other tropical neuromyelopathy epidemics associated to severe nutritional deficiencies that affected war prisoners during World War II which is usually combined to tropical malabsortion (Román et al. 1985).

Román (1994) underlines that despite the absence of overt malnutritrions in the Cuban population, a deficit of vitamins from group B, mainly thiamine, followed by lack of essential sulfur containing amino acids in diet, and the increased consumption of cane sugar, appears to have been responsible for the outbreak.

Many studies (Dang 1981, Oku et al. 1991) consider smoking and substances derived from it as important factors in optic and nervous diseases. Although it was not significantly identified in the multivaried analysis, its influence can not be disregarded, especially since its exclusion affects association to the suspected viral infection. Besides, it is known that the four non-smoking patients are actually passive smokers, except one. There were no significant differences when comparing smoking with non-smoking patients, equitatively predomination groups with a consumption rate of 1 to 10 and 11 to 20 cigarrettes. Some childhood exanthematous diseases like rubella, measles and varicella, and others like dengue, hemorrhagic conjuntivitis could turn individuals more susceptible to neuropathy or on the contrary, could also be an immunological defense that, together with other factors, facilitates a strong response with the infection of some agents. For example, the suspected enterovirus isolated from some of our patients that sometimes shows an atypical behaviour like a light cytopathic effect (Más Lago et al. 1993).

It should be pointed out that, in large outbreaks of hemorrhagic conjuntivitis, there is a low inci- 
dence of the paralysis similar to poliomielitis, which includes cranial nerves, lumbosacral radiculomielitis and paralysis of inferior motoneuron. These symptoms usually appear from a few days and a month after conjuntivitis and they commonly leave a certain residual weakness (Benenson 1992). In our study we found that this antecedent was associated.

Three hundred and forty two people participated in the serological survey. It showed $73.7 /$ 100 of antibodies prevalence with a variability from 68.7 to 78.3. As it was expected, there is higher prevalence in infants, and a high prevalence of antibodies in adults that explain the dissemination of the Coxsackie A-9 (strain 47) in the community. Antibodies prevalence was higher in zone A (85/100), the same area with a higher rate of EN (rate 3.0/100). We do not have a clear explanation, as to why this situation came up in the zone with the best sanitary conditions, except the crowd that exist in similar urban regions. On the other hand, we did not find association with the presence of vectors or animals.

In the SMON ocurred in Japan, studies were also made of some viral agents ECHO 21, Coxsackie A, among them, haerpes and others that produce a cytopathic effect, similar to ours. Furthermore, some authors have reported high antibody prevalence against ECHO 21 virus in regions with a high SMON prevalence. Considering this, they suggested an abnormal reactivity from patients with SMON for a reinfection to ECHO 21 virus (Tagaya 1975, Kono \& Ishii 1990). All these results may help us to interpret some of our data including the fact that the disease occurred more in adults.

We have insisted in pointing out new evidences as to a possible association of Coxsackie A-9 virus isolated to the occurrence of neuropathies, to explain its participation. It is also important to show the results of the multiple logistic regression analysis, since it is a model that allows us to control possible confusing variables and evaluates the interaction of a group of variables which is very useful from the epidemiological point of view in such a complex problem.

The best adjustment of this model was obtained by interacting age variables, linder and the consumption of edible fat of non-certified origin, as well as the antecedents of hemorrhagic conjuntivitis together with an exposure to the virus. Although smoking did not have a statistic significance, it may play an important role. Since when you eliminate it, other factors (including positive serology) loose their association.

When stratifying the analisis to patients over 24 years of age, there is a better adjustment of the model with the variables mentioned above, though age looses statistical significance, as expected; however, it is an influential factor since when it is not included, a significant loss is observed (particularly in serology).

Some of the factors and antecedents previously analized in isolation are evident, thus stresses their role or association in the ocurrence of this disease.

In essence, such virus, together with age, antecedents of haemorrhagic conjuntivitis, the consumption of linder (that could be a symptom of stress) together with some toxic substances and the lack of some micronutrients seem to be part of the origin of neuropathy.

Despite the detailed study developed, the ethiologic complexity of this problem is such, that we have not reached a final result, what will lead us to future research work with the available data.

\section{ACKNOWLEDGEMENTS}

To Drs Raydel Martínez, Plácido Pedroso, Manuel Díaz for their cooperation and the Epidemiology Master students for performing the Epidemiological Survey. To recognize the help of Alberto Baly, Susana Vázquez, José Laferte, Maritza Soler, Mariela Otaño and the clinical technicians of the laboratory.

\section{REFERENCES}

Balmaseda A, Laferte J, Soler M, Vázquez S, Rodríguez L, Otero A, Vázquez V 1995. Utilización del ELISA y el ultramicroELISA en la identificación de una cepa de Coxsackie A-9 aislada durante la epidemia de neuropatía en Cuba. Rev Cub Med Trop 44: 44-49.

Benenson AS 1992. Haemorrhagic Conjuntivitis, p. 6669. In The control of communicable diseases in man. Scientific publication Number 538, 15 Ed. OPS/ OMS.

Dang CV 1981. Tobacco-alcohol amblyopia: a proposed biochemical basis for pathogenesis. Med Hypothesis 7: 1317-1328.

Fleiss JL 1981. Inferences about a single proportions, p. 14-15. In Statistical Methods for Rates and Proportions, 2nd. ed. John Wiley and Sons, USA.

Kono R 1975. Introductory review of subacute myelooptico neuropathy (SMON) and its studies done by the SMON research commission. Jap J Med Sci Biol 28:1-21.

Kono R, Ishii K 1990. Echovirus 21 theory p. 30-33. In History and review of SMON research. English translation by the SMON Research Committee supported by a Japanese Ministry of Health and Welfare Research Grant,1989.

Más Lago P, Pelegrino J, Guzmán M, Capo V, Rodríguez L, Rodríguez P, Kourí G 1995. Neuropatía Epidémica cubana. Parte I. Aislamiento viral. Rev Cub Med Trop 47:11-15

Más Lago P, Rodríguez MP, Guzmán MG, Alvárez M, Muzio V, Ancheta O, Goyenechea A, Roca H, Morier L, Alvarez R, Marrero M, Musachio A, Castillo A, Falcón V, Pelegrino JL 1993. Preliminary results of the virologic laboratory on the study 
of Epidemic Neuropathy in Cuba. Epidemiol Bull $I P K$, Special issue 1: 7-8.

MINSAP 1993 Epidemic Neuropathy the diagnostic criterion. Epidemiol Bull IPK, Special Issue 1: 5-7.

MINSAP 1994. Epidemic Neuropathy - Cuba, 19911994. MMWR 430: 183-192.

Oku H, Fukushima K, Miyata M, Wakakuva M, Ishikawa S 1991. Cyanide with vitamin B12 deficiency as the cause, of experimental tobacco amblyopia. Acta Soc Ophthamol JPN 95: 158-164.

Román GC 1994. Epidemic Neuropathy in Cuba: A plea to end the United States economic embargo on a humanitarian basis. Neurology 44: 1784-1786.

Román GC, Spencer PS, Schoenberg BS 1985. Tropical myeloneuropathies: the hidden endemias. $\mathrm{Neu}$ rology 35: 1158-1170.
Rosling H 1988. Cassava toxicity and food security. A review of health effects of cyanide exposure from cassava and of ways to prevent these effects, Uppsala: Sweden International Child Health Unit University Hospital. UNICEF.

Tagaya I 1975. Summarized report of reserach works by the members of the virology subsection. The microbiology section. Jap J Med Sci Biol 28: 197202.

Tamura Z 1975. Clinical chemistry of clioquinol. Jap J Med Sci Biol 28: 69-77.

Tylleskar T, Banea M, Bikangi N, Fresco L, Persson LA, Rosling H 1991. Epidemiological evidence from Zaire for a dietary ethiology of konzo, an upper motor neuron disease. Bull WHO 69: 581-589. 